\title{
THE MODERATING EFFECT OF DIRECTORS' NETWORK TOWARDS TECHNOLOGICAL INNOVATION AND FIRMS' PERFORMANCE: A CONCEPTUAL PAPER
}

\author{
Shah Rol Hussain ${ }^{1, *}$, Fathyah Hashim¹, and Mohd Faizal Jamaludin ${ }^{2}$ \\ ${ }^{1}$ Graduate School of Business, Universiti Sains Malaysia, Penang, Malaysia \\ 2Department of Commerce, Politeknik Tuanku Sultanah Bahiyah, Kulim, Malaysia
}

\begin{abstract}
Scholars have given increased attention to seek for a solution to improve firms' performance. The literature demonstrated that technology innovation is considered the most powerful means of firms' performance for modern companies. Empirical findings showed, however, that the relationship between technological innovation and firms' performance continues to be inconclusive as it has a negative, positive or no impact on firms' performance. In order to address such gap, this paper proposes a theoretical framework to describe the moderating effect of directors' network on technological innovation and firms' performance. It shows that the effectiveness of business innovation can be enhanced through direct or indirect use of each network of directors. The firm still neglects the significant capacity of the board of directors' network in a firm. In short, the crucial discussion found in this paper will lead to improving the information on innovation, networking and organizational studies as well as act as a reference to study in other countries. This study is a promising field. The business will benefit from a large social network of directors. Thus, the company is proposing to fully utilize the function of directors' network to leverage the innovation activities and firm's performance.
\end{abstract}

ARTICLE HISTORY

Received: $31-5-2020$

Accepted: $1-9-2020$

\section{KEYWORDS}

Technological Innovation, Directors' Network,

Firm Performance

\section{INTRODUCTION}

Firms' performance in an organizational study is one of the crucial topics (Miller, Washburn, \& Glick, 2013) and has been commonly used as a dependent variable by many researchers. To stay ahead of the competition, each firm should improve its performance. Those who pursue to innovate and achieve greater performance can hold the winning card. Technological innovation is one of the main determinants of firms' performance (Feeny \& Rogers, 2003). The business with high rates of innovation appears to improve its performance more quickly than those without innovation (Roper, Du, \& Love, 2008). Since 2000, 52\% of companies of fortune 500 have either failed or been bought over or ceased to exist as reported in the Harvard Business Review in 2017 (Tekic \& Koroteev, 2019) due to the transformation on innovation, efforts were much delayed. This claim is consistent with Schumpeter's theory of innovation profit, which leads to winners and losers being visible in the market (Yildiz, Bozkurt, Kalkan, \& Ayci, 2013).

The need for technological innovation is vital in the Malaysian context in helping Malaysian businesses to stay competitive and gain greater performance. The innovation may enable the firm to improve the Gross Domestic Product (GDP) growth. However, The World Bank (2020) showed that Malaysia's GDP growth rate dropped from $7.53 \%$ in 2010 to $4.33 \%$ in 2019. The downward trend in the percentage of Malaysia's GDP means Malaysian firms' performance is declining. Rasiah and Yap (2016) argued that the slow pace of Malaysia's GDP since 1997 is primarily due to poor performance in innovation. The more successful businesses are, the more they contribute to GDP growth. GDP is a significant factor in the company's success evaluation (Dimitras, Kyriakou, \& Iatridis, 2015). The slow growth can be described as the performance of a company experiencing a sales and earnings decline.

This finding is consistent with firms' performance issues in Malaysia showing that Malaysia lacks business confidence with a score of 85.50 points in January 2020 and Malaysia firms have high bankruptcy rates. Since the year 1998 to 2015 , it was recorded that the average number of bankrupt companies per year was 1250 companies in which July 2013 recorded the highest level with 2366 companies. Meanwhile, the lowest record was in February 1999 with 503 companies (Tradingeconomics, 2020). As GDP growth declines, the financial performance of firms may decline too.

Therefore, it is time for Malaysian companies to come up with the best alternative approach to upgrade their company to continue innovating. Innovation can develop ideas, generate value, and improve company performance. The empirical findings on the relationship between technological innovation and business performance are contradictory as they have shown significant, negative, or no impacts of innovations on business performance (Cruz-Cázares, Bayona-Sáez, \& García-Marco, 2013). Surprisingly, not all companies fully utilize the advantages of directors' networks especially in terms of corporate innovation. As argued by Jamaludin and Hashim, (2017), little is known about the effect of directors network. Besides, it might help the company to increase its innovation activities while also enhancing its performance. The firm has always been connected (Chen, Wei, \& Liu, 2019) with other parts outside the firm. This relation also affects the success and development of businesses. 
From a resource-based perspective and a social capital theory perspective, networking and technological innovation are potentially valuable resources for firms and their management (Li, 2019). Director networking not only enables firms to have information access and communities of practice (Andrikopoulos, Georgakopoulos, Merika, \& Merikas, 2019) but also makes it possible for organizations to transfer knowledge among themselves. Nonetheless, there is also evidence that networking knowledge may not be applicable to companies resulting in appointed directors being incapable to operate efficiently (Carpenter \& Westphal, 2001). Li (2019) claimed that a business has the ability to access significantly distinct information that could enhance technological innovation by creating a relationship with companies in different industries.

To date, for both academia and practitioners, the link between technical innovation and firms' performance has been a topic of interest. Nevertheless, the moderating impact of directors' network on technological innovation and firms' performance is still limited. This paper explored the relationship between technological innovation, the directors' network, and its effects on firms' performance to resolve the gap in the literature by suggesting that technological innovation has a positive effect on firms' performance and that the directors' network plays a key role in moderating it.

\section{LITERATURE REVIEW}

\section{Technological Innovation}

The most powerful sources of firms' performance in modern organisations are technological innovation. A business that can effectively introduce technological innovation also has a strong market orientation (Lin, Lee, \& Hung, 2006) and driven economic growth (Kim, 2019). Nowadays, the word innovation becomes the main agenda in business and its synonym for the company's survival and development, thus, "innovate or die" (Xin, Chen, Zhang, \& Sun, 2019; Abbasi, Motavasseli, Zali, Faghih, \& Meigounpoory, 2019)

Technological innovation is intended to establish market value (Liao, Liu, \& Zhang, 2018) and increase firms' performance (Nwosu, Awurum, \& Okoli, 2015; Rahim \& Zainuddin, 2019). It is evident in the history of business that successful innovators are more likely to succeed (Chen \& Ibhagui, 2019) and those who do not progress appear to not survive in the sector (Azubuike, 2013). In the sense of organizational structures, procedures, goods, and services in the business, technology innovation are often regarded as the critical component of competitiveness (Chege, Wang, \& Suntu, 2020). It has been seen as the key contributor to the development master plan to participate in emerging sectors thus increasing current business monopolization (Hagspiel et al., 2020). Hence, it provides the business with a competitive advantage (Yigitcanlar, Sabatini-Marques, Da-Costa, Kamruzzaman, \& Ioppolo, 2019).

Innovation also affects how a company is managed. A study by Walsh and Linton (2002) argued that technological innovation is a company-owned specific technique or production method that makes a quick reaction to a change in business climate change. Moreover, innovative technology is believed to enhance the company's efficiency by leveraging dynamic knowledge and competence network especially related to the director's network (Li, 2019). Archibugi and Coco (2005) made a point by saying that technical innovation is the capacity to access, digest, and effectively deliver a new product and use it to dynamically refine, grow, and implement external information. From the abovementioned studies, technology innovation is capable to contribute as one of the critical roles for the purpose of predicting a firms' performance to be more effective and competitive in the market.

Despite the evidence of how technological innovation becoming the center of importance, surprisingly, there are only a few studies concerning the connection involving the directors' network, technological innovation, and the firms' performance. Studying the role of the directors' network has important consequences for practitioners and academicians and can provide additional insights into the determinants of technological innovation. However, this can also deepen awareness of the nature of the directors' network in a broad sense.

Unfortunately, from the standpoint of innovation evaluation, the efficiency of the process of innovation is not being assessed in a homogenous manner, and this lack of consensus inhibits the mechanism of generating competitive gains from an innovative organisation. For innovation measures such as R\&D, patents, patent citations, or new product announcements, many studies used the same metric or single indicator, and the others employed two indicators or more to generate one construct. Given the complexity and contradictions in the meanings of the structures, measures, collected samples, databases, industries, and country environments, it seems that the principles and metrics of innovation can hardly be interpreted and analyzed in depth. However, the advantages of using a multi-indicator approach are those indicators may permit researchers to be able to calculate creative success utilizing more complicated and detailed measures. According to OECD/Eurostat (2018), there are two classes of indicators relevant to the measurement of innovation and performance such as resources devoted to R\&D and patent statistics.

\section{Technological innovation in Malaysia}

Malaysia is one of the world's developing countries and is listed as a high-medium country with a gross per capita income of US\$10,449 (Julian \& Ahmed, 2019). Malaysia has created and implemented various technical strategies and policies to boost technological innovation efficiency. It started in 1986 with the announcement by the government on the first National Science and Technology Policy 1 (NSTIP 1) to outline a framework for achieving the growth of Science, Technology, and innovation development. In 1990, an Industrial Technology Development Action Plan has been developed to address NSTIP 1 vulnerabilities (Bekhet \& Latif, 2017).

The second NSTIP2 agenda was announced under the $10^{\text {th }}$ Malaysia Plan $(2011-2015)$ by the government to redesign and set the Science, Technology, and Innovation (STI) Strategic Guideline for Malaysia to achieve the mission to become an innovative economy by 2020 . Nevertheless, some of the issues in the past initiatives, including the diffusions of 
technology, investment from the private sector to R\&D and technological innovation, commercializing of products and services, and monitoring and evaluation issues have not been enforced (Rasiah \& Chandran, 2015). Throughout its agenda for 2013 until 2020, many ministries showed participation and many organizations, groups, and initiatives have been created and organized (Bekhet \& Latif, 2017).

In the perspective of the world ranking, the latest Global Innovation Index (2019) has reported that Malaysia is currently ranked 35 out of 143 countries in 2019 with a score of 42.68. It dropped from rank 25 in 2009, rank 31 in 2011 , and ranked 33 in 2013. The significant decrease in rank is due to other countries has improved their standing far greater than Malaysia (Rasiah \& Yap, 2016). Thus, the organization is proposed to increase its technological innovation activities in order to guarantee that Malaysia is competitive on the market and represents its business success.

Malaysia is facing a slow pace in innovation due to various reasons and its impact on firms' performance is reflected in the documents and official reports. Firstly, there is still a lack of cooperation between universities and businesses. The findings from public research institutions do not match the industry requirement (CEDAR, 2018). Product developers are often hesitant to implement new technologies built locally in their products. The lack of expectations between researchers and industry happened in which researchers from university argued that the method used must be of high efficiency but not necessarily improve the bottom line of user experience. This also contradicts the industry that wants a simple and user-friendly solution (Malaysia Productivity Corporation, 2019)

Secondly, R\& D, and innovation activities are often constrained by inadequate resources (Julian \& Ahmed, 2019). While R\&D and innovation activities are also supported by universities, they do not meet the demands of the industry. Thirdly, industry players are more likely to use current technology without upgrades and have lagged in technological growth compared to the newly industrialised economies. It is time to boost Malaysia to manufacture, design, and create new products from the assembly phase (Chandran, Rasiah, \& Wad, 2009). Malaysia may emulate the achievement of South Korea and attain goals to be a highly-income country if it can manage technical and innovation activities effectively. Therefore, the involvement of local companies should be intensified to ensure the goal of being an innovation hub is achieved and the firms' performance can be improved.

\section{Firms' Performance}

Taouab and Issor (2019) proposed that the firms' performance is a result obtained by management in providing competitiveness, profitability, and effectiveness to the firm. Since this indicator tests the productivity and effectiveness operation of businesses (Neely, Gregory, \& Platts, 2005), the companies' accomplishments are the first to be measured by investors worldwide (Al-Matari, Al-Swidi, \& Fadzil, 2014). This was also deemed important as it showed how businesses grow and function over time. The results must be measurable in order to be significant (Al-Matari et al., 2014). Effective management (Selvam, Gayathri, Vasanth, Lingaraja, \& Marxiaoli, 2016) of any company is crucial in measuring performance. Process improvement can only be achieved if the result is measured. Improved organizational performance, therefore, requires assessment to identify firms' performance levels (Al-Matari et al., 2014) through the use of organizational resources (Homroy \& Slechten, 2019).

The comprehensive summary of previous research provided a myriad of ways for measuring firms' performance and they can be divided into two categories (Al-Matari et al., 2014; Selvam et al., 2016). The classification of predictors for firms' performance as proposed by Selvam et al. (2016) is divided into two aspects, including financial and strategic performance. Financial performance covers three variables, namely revenue and profit performance, productivity performance, and open market valuation performance, while strategic performance includes six other variables, such as employee engagement, customer satisfaction, environmental performance, environmental audit performance, corporate governance performance, and social performance. Profitability measures a company's past ability to generate returns. Market value performance refers to market prices. The financial asset, such as the share of a company, should have a market value. Market value is also commonly used to refer to the market capitalization of a publicly-traded company and is obtained by multiplying the number of its outstanding shares by the current share price.

In the same sense, Al-Matari et al. (2014) argued that firms' performance measurement may be classified into two classifications, which include accounting-based measurement and market-based measurement. Accounting-based measurement is usually known to be an effective measure for the profitability and performance of a business when compared to the benchmark rate of return which equals the risk-adjusted weighted average cost of capital. The marketbased assessment is best described by its forward-looking nature and reflects the expectations of the shareholders regarding the future performance of the company, which is based on previous or current performance. Indeed, accountingbased measures can reflect the company's past performance, while market-based indicators help to predict future performance. Table 1 shows the sample indicators for accounting-based assessment and market-based assessment. 
Table 1: Indicators of measurement sample under accounting and market-based category

\begin{tabular}{|c|c|}
\hline \multicolumn{2}{|r|}{ Accounting-Based Measurement } \\
\hline Indicator & $\begin{array}{c}\text { The author } \\
\end{array}$ \\
\hline $\begin{array}{l}\text { Return on Equity } \\
\text { (ROE) }\end{array}$ & (Pislaru, Herghiligiu, \& Robu, 2019; Wu \& Gu, 2018; Ravšelj \& Aristovnik, 2020) \\
\hline Return on Sales (ROS) & (Han, Dong, \& Dresner, 2012; Wu, Chen, Chen, \& Chien, 2019; Bharadwaj, 2000) \\
\hline $\begin{array}{l}\text { Return on Investment } \\
\text { (ROI) }\end{array}$ & $\begin{array}{l}\text { (Pislaru et al., 2019; Liao et al., 2018; Alshehhi, Nobanee, \& Khare, 2018; Lee, Kwon, \& } \\
\text { Pati, 2019a; Wang, 2019) }\end{array}$ \\
\hline $\begin{array}{l}\text { Return on invested } \\
\text { capital (ROIC) }\end{array}$ & $\begin{array}{l}\text { (Ramli et al., } 2019 \text {; Alam, Uddin, Yazdifar, Shafique, \& Lartey, 2020; Koellinger, 2008; } \\
\text { Lin, Yip, Ho, \& Sambasivan, 2020) }\end{array}$ \\
\hline Profit Margin (PM) & (Ghapar, Brooks, \& Smyth, 2014; Al Manaseer, Al-Hindawi, Al-Dahiyat, \& Sartawi, 2012) \\
\hline $\begin{array}{l}\text { Earning s per Share } \\
\text { (EPS) }\end{array}$ & (Jakpar, Tinggi, \& Hui, 2019; Cazavan-Jeny \& Jeanjean, 2006; Alarussi \& Alhaderi, 2018) \\
\hline \multicolumn{2}{|r|}{ Market-Based Measurement } \\
\hline Indicator & $\begin{array}{l}\text { Authors } \\
\end{array}$ \\
\hline Tobin Q & $\begin{array}{l}\text { (Zuo, Fisher, \& Yang, 2019; Wesselman, 2017; Chen \& Ibhagui, 2019; Kim, 2019; Lee et } \\
\text { al., 2019a) }\end{array}$ \\
\hline
\end{tabular}

Source: Developed from various studies including Al-Matari et al., (2014)

The research on firms' performance suffers from problems such as the selection of measurement indicators. In this respect, there is incomplete literature and on-going debate on the issue of the firms' performance. Most prior research assessed firms' performance using one single indicator (Miller et al., 2013). Since there were several dimensions, Selvam et al. (2016) suggested that new researchers should use more than one dimension to ensure that the findings are clearly conceptualized and that their sizes, measurement, and performance are discussed effectively.

\section{Directors network in technological innovation}

Prior studies showed that the director's network is closely linked to technical innovation (Chen et al., 2019; Li, 2019). The effectiveness of corporate innovation activities can be increased by directly or indirectly leveraging each director's network. However, Jamaludin and Hashim (2017) contended that the company still neglects the significant role of the director's network in the firm. A similar idea was proposed by Hamid (2011) which stated that the need to nominate and retain a member of the board was less concerned with the influence of the networks of the director. Therefore, if the issue remains and no corrective measures have been taken by the firm, it means that this valuable resource was left unused. This is a loss for the company.

Director's network can be interpreted as the directors' connection or directors' interlock, established based on direct ties created by at least one common board during service. The directors, as suggested by Wincent, Anokhin, and Örtqvist, (2010) are linked through meetings and discussions while exchanging knowledge and information across their network (Wang, Jean, \& Zhao, 2020). Information exchange is one of the primary functions of the directors' network towards innovation. Allen (1977) argued that the directors are known as "gatekeepers", who had more informal contacts outside different companies which were crucial in sharing new information and linking it with the firm. Helmers, Patnam, and Rau, (2017) stated that the Indian companies have increased their propensity to patent as a response to an increase in their level of directors networking. As a result, the greater the network connectivity of the director, the more technological information is provided and more innovation activities of the company can be leveraged.

This evidence is strengthened by looking at the case of Tube Investment of India Ltd, operating in the based metals industry. After this company appointed Mr. Murugappan using the directors' network resources, the company witnessed an increase in R\&D investment for Tube Investment of India Ltd to US\$ 530,000 by the end of 2004, an increase of approximately $35 \%$ compared to the year before. Therefore, board interlocks may lead to increased R\&D spending by fostering the transfer of new knowledge that will enable the firm to perform better in technological innovation (Helmers et al., 2017).

The second role is the advisor. Carpenter and Westphal (2001) here argued that the directors' network offers better advice and guidance to boost the performance of firms in innovation. The third role is monitoring. Helmers et al. (2017) concluded that a blend of advising and monitoring roles could improve the company's innovation activities by the directors' network. Directors' networks also deliver reputational incentives that increase the willingness of directors to efficiently advise and monitor management actions (Shaw, Cordeiro, \& Saravanan, 2016). Additionally, directors' network may increase the board network capital. Wincent et al. (2010) concluded that innovative output is strongly affected by directors' networks. The network capital of the board refers to the whole spectrum of knowledge, skill, experience, and abilities that produce a conclusive output.

When directors serve on various boards, they build ties with other companies and provide an opportunity to exploit them (Caiazza \& Simoni, 2015), which may be converted into certain benefits even if they may cause disadvantages as well. The negative side of the network of directors on organizational innovation can be divided into many areas based on the literature review. Firstly, the directors' network can impede technological innovation activities in firms. A wellconnected board could also be a busy board, as directors can sit on multiple boards and take part in many social events. They appear to spend less time offering advice on strategic innovation initiatives (Bhuiyan \& Roudaki, 2018) and do not 
work as effective monitors (Fich \& Shivdasani, 2012). However, Roudaki and Bhuiyan (2015) argued that busy directors are good for the company because they have more diverse knowledge and experience.

Secondly, Shaw et al. 2016, and Oh, Labianca, and Chung (2006) argued that multiple directorships may result in overcommitment, correlated with poorer governance. This also may result in companies being inadequately advised which can cause less profitability. Finally, the information channel is an essential tool provided by the directors' network. Nonetheless, Larcker, So, and Wang (2013) concluded that if the information is not accurate or wrong, the data could spread negative practices (Baran, 2017), for example backdating (Bizjak, Lemmon, \& Whitby, 2009) and income management (Chiu, Teoh, \& Tian, 2013). This situation can eventually damage the credibility of the business and firms' results (Shaw et al., 2016).

Prior to this research, the positions of the directors' network and their significant effect on technological innovation were discovered. Some preliminary findings demonstrated the positive effects as well as some negative effects. The basic influence of the network of directors should be utilized to encourage technological innovation in companies. In this research, Malaysia can support local companies by providing a strong social network for a local climate. The next segment of this paper focuses on the theoretical framework and hypothesis.

\section{HYPOTHESIS AND THEORETICAL FRAMEWORK}

\section{Theoretical framework}

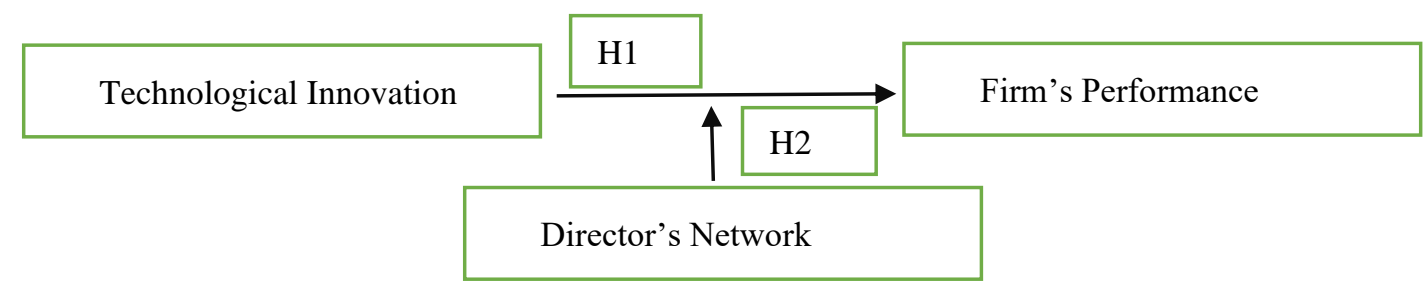

Figure 1: Theoretical framework

The theoretical framework was drawn up from the literature review and outlined in Figure 1. The relationships between the dependent (firms' performance) and the independent (technological innovation) variables proposed to be calculated by ROA, ROE, ROIC, Tobin Q was demonstrated. The moderating influence of the director's network on independent and dependent variables was also calculated.

\section{The link between technological innovation and firms' performance}

Numerous studies suggested that the impact of technological innovation on firms' performance is substantial (Xin et al., 2019). Many researchers around the world supported this suggestion. Increasing investment in innovation by firms tends to provide better financial statistics in the manufacturing industry of the Czech Republic (Bockova \& Zizlavsky, 2016). Technological capabilities in Malaysia and Vietnam impact significantly on competitive advantages and company performance in the automotive industry (Rahim \& Zainuddin, 2019), as well as in the agriculture sector (Ho, Nguyen, Adhikari, Miles, \& Bonney, 2018). Lee, Lee, and Garrett (2019) also suggested that the success of low-tech firms in South Korea would have a direct and positive effect on organizational innovation.

Innovation is considered to be one of the main drivers of firms' performance (Azubuike, 2013; Hervas-Oliver, Albors Garrigos, \& Gil-Pechuan, 2011). Therefore, innovation has a positive impact on the growth, market, and financial results of the business (Azubuike, 2013). Roper et al. (2008) argued that if the organization has a high level of innovation, its performance may be improved. Since they can manufacture a range of goods and services using technological innovations, the company can have high performance and profits (Camisón \& Villar-López, 2014).

A company that effectively brings technological innovations to the marketplace is also extremely market-oriented (Lin et al., 2020). In comparison to non-tech innovation, technical innovation has a greater impact on business efficiency and growth (Ryu \& Lee, 2015). Wang (2019) showed that technological innovation and corporate success have produced mixed results. The author found that radical innovation is good for business success but it has a negative impact on mainstream innovation strategies.

With regard to the empirical data mentioned above in the literature, an important relationship was established between the performance of a company and technological innovation. Therefore, this study proposed the hypothesis as follows:

Hypothesis 1: Technological innovation is positively related to firms' performance.

\section{Moderating effects of the director's network on technology innovation and firms' performance}

Prior research has largely assumed that network of directors could lead to innovation and technology activities to improve company performance. Studies in emerging economies such as India (Helmers et al., 2017) have shown that the Indian firms' network of directors boosts innovation in R\&D and patenting performance. Researchers from Spain (Hernández-Lara \& Gonzales-Bustos, 2019), China (Han, Bose, Hu, Qi, \& Tian, 2015), Thailand (Peng, Au, \& Wang, 2001), Malaysia (Rohaida, Hasnah, Kamarun Nisham, \& Noriah, 2013) and Hong Kong (Au, Peng, Mike, \& Wang, 2000) also claimed that firms with high-level network directors benefited from better organizational effectiveness. Singh and 
Gaur's (2009) pooling data for the top 500 Indian and Chinese companies showed that group members were weaker than non-affiliated companies and the negative relationship in Indian firms was greater than in China's. Therefore, there is a valuable link between the directors' networks (Shaw et al., 2016), which can boost firms' performance.

Investing in research and development by championing the communication of new knowledge by directors (Han et al., 2015) has allowed a company to carry out new studies. This can lead to a long-term increase in shareholder assets. Gomes-Casseres, Hagedoorn, and Jaffe (2006) showed that the flow of knowledge among allied firms is higher than those between companies without alliances in terms of patenting performance.

Past researchers demonstrated that the directors' networks can help companies access information that is vital to technological activities (Wu \& Dong, 2020), be a major corporate innovation mechanism (Jiang, Yang, Zhao, \& Li, 2020), and help to achieve company performance (Larcker et al., 2013). Wu and Dong (2020) argued that the connectivity of directors of the company in China has a significant positive effect on corporate innovation. For Italian manufacturing firms, Medda, Piga, and Siegel (2006) reported seeing improved efficiency and firms' output through partnering with other companies in the field of research and development.

From the previous discussion, it can be concluded that the directors' network has an impact on technological innovation and firm performance. Thus, this paper proposed the hypothesize that follows:

Hypothesis 2: The relationship between firms' performance and technological innovation is moderated in a way that technological innovation is considered to have a positive effect on results when the directors' network exhibit high.

\section{METHODOLOGY}

The methodology for this study was a library search and the analysis of prior known documentation in the field of directors' network, technological innovation as well as firms' performance was held too. Online and offline material from article journals, books, and agency reports were included in the library search. Online databases such as Scopus, Google Scholar, Science Direct, and the Science web were used as references and some were chosen from the conference journal. For the systematic search, the final search query was given by the word directors network, director interlock, firms' performance, technology, technological innovation, and innovation. It was acknowledged that other keywords can be relevant or interesting, but this study believed that the above keywords are sufficient to cover the key criterion. The limitations in this study could also be due to restricted resources from the database, as the search results were excluded on health studies, science, and education field that connected to the impact of the directors' network on technological innovation and firm performance. Moreover, the references used were not restricted only to innovation and firms' performance in Malaysia but also taking into consideration global transformation.

\section{CONCLUSION}

In short, this conceptual paper proposed a theoretical framework to describe the moderating effect of directors' network on technological innovation and firms' performance. The combination of these three variables will make it possible for researchers to further explore the area of network innovation. The directors' network has been seen as one mechanism that a company can use to access resources. Prior research largely inferred that the network of directors may lead to improve technological innovation activities and enhance the firms' performance but empirical evidence is required to prove this link.

Nevertheless, since this paper is conceptual, no data were collected to allow generalization to other nations. Furthermore, the structure of this analysis was based on previous literature. Generalization is therefore not appropriate. The same study was promoted in other countries, and various angles to technological innovation may apply. The main recommendation in this paper is that technological innovation has a positive impact on firms' performance and the directors' network plays a crucial role in moderating this effect.

\section{REFERENCES}

Abbasi, F., Motavasseli, M., Zali, M. R., Faghih, N., \& Meigounpoory, M. R. (2019). How Does the Technological Innovation Come From? a Multilevel Framework. International Transaction Journal of Engineering Management \& Applied Sciences \& Technologies, 10(4), 527-550. https://doi.org/10.14456/itjemast.2019.50

Al-Matari, E. M., Al-Swidi, A. K., \& Fadzil, F. H. (2014). The Measurements of Firm Performance's Dimensions. Asian Journal of Finance \& Accounting, 6(1), 24. https://doi.org/10.5296/ajfa.v6i1.4761

Al Manaseer, M. F., Al-Hindawi, R. M., Al-Dahiyat, M. A., \& Sartawi, I. I. (2012). The effect of corporate governance characteristics on the performance of jordanian banks. European Journal of Scientific Research, 67(3), 349-359.

Alam, A., Uddin, M., Yazdifar, H., Shafique, S., \& Lartey, T. (2020). R\&D investment, firm performance and moderating role of system and safeguard: Evidence from emerging markets. Journal of Business Research, 106(November 2018), 94-105. https://doi.org/10.1016/j.jbusres.2019.09.018

Alarussi, A. S., \& Alhaderi, S. M. (2018). Factors affecting profitability in Malaysia. Journal of Economic Studies, 45(3), $442-458$. https://doi.org/10.1108/JES-05-2017-0124

Allen, T. J. (1977). Managing the Flow of Technology | The MIT Press. Retrieved July 16, 2020, from MIT Press website: https://mitpress.mit.edu/books/managing-flow-technology

Alshehhi, A., Nobanee, H., \& Khare, N. (2018). The impact of sustainability practices on corporate financial performance: Literature trends and future research potential. Sustainability (Switzerland), 10(2). https://doi.org/10.3390/su10020494

Andrikopoulos, A., Georgakopoulos, A., Merika, A., \& Merikas, A. (2019). Corporate governance in the shipping industry: board interlocks and agency conflicts. Corporate Governance (Bingley), 19(4), 613-630. https://doi.org/10.1108/CG-07-2018-0224 
Archibugi, D., \& Coco, A. (2005). Measuring technological capabilities at the country level: A survey and a menu for choice. Research Policy, 34(2), 175-194. https://doi.org/10.1016/j.respol.2004.12.002

Au, K., Peng, Mike, W., \& Wang, D. (2000). Interlocking directorates, firm strategies, and performance in Hong Kong: Towards a research agenda. Asia Pacific Journal of Management, 17(1), 29-47. https://doi.org/10.1023/a:1015432819596

Azubuike, V. M. U. (2013). Technological Innovation Capability and Firm's Performance in New Product Development. Communications of the IIMA, 13(1), 43-56. Retrieved from http://scholarworks.lib.csusb.edu/ciima/vol13/iss1/4

Baran, L. (2017). Director connectedness and firm value in S\&P 500 Index reconstitutions. Journal of Economics and Business, 92 , 63-79. https://doi.org/10.1016/j.jeconbus.2017.06.001

Bekhet, H. A., \& Latif, N. W. A. (2017). Highlighting Innovation Policies and Sustainable Growth in Malaysia. International Journal of Innovation, Management and Technology, 8(3), 228-239. https://doi.org/10.18178/ijimt.2017.8.3.734

Bharadwaj, A. S. (2000). A resource-based perspective on information technology capability and firm performance: An empirical investigation. MIS Quarterly: Management Information Systems, 24(1), 169-193. https://doi.org/10.2307/3250983

Bhuiyan, M. B. U., \& Roudaki, J. (2018). Related party transactions and finance company failure: New Zealand evidence. Pacific Accounting Review, 30(2), 199-221. https://doi.org/10.1108/PAR-11-2016-0098

Bizjak, J., Lemmon, M., \& Whitby, R. (2009). Option backdating and board interlocks. Review of Financial Studies, 22(11), 48214847. https://doi.org/10.1093/rfs/hhn120

Bockova, N., \& Zizlavsky, O. (2016). Innovation and financial performance of a company: A study from Czech manufacturing industry. Transformations in Business and Economics, 15(3), 156-175.

Caiazza, R., \& Simoni, M. (2015). Directors' role in inter-organizational networks. Corporate Governance (Bingley), 15(4), 508-516. https://doi.org/10.1108/CG-05-2014-0059

Camisón, C., \& Villar-López, A. (2014). Organizational innovation as an enabler of technological innovation capabilities and firm performance. Journal of Business Research, 67(1), 2891-2902. https://doi.org/10.1016/j.jbusres.2012.06.004

Carpenter, M. A., \& Westphal, J. D. (2001). The Strategic Context of External Network Ties: Examining the Impact of Director Appointments on Board Involvement in Strategic Decision Making. Academy of Management Journal, 44(4), 639-660. https://doi.org/10.5465/3069408

Cazavan-Jeny, A., \& Jeanjean, T. (2006). The negative impact of R\&D capitalization: A value relevance approach. European Accounting Review, 15(1), 37-61. https://doi.org/10.1080/09638180500510384

CEDAR. (2018). Manufacturing in Malaysia : Main Issues and Challenges ( Jan 2018 ). Cedar Web Portal, 1(Jan 2018), 1-4. Retrieved from https://www.cedar.my/knowledge-management/industry-article-2.

Chandran, V. G. R., Rasiah, R., \& Wad, P. (2009). Malaysian Manufacturing Systems of Innovation and Internationalization of R \& D. In CBDS Working Paper Series.

Chege, S. M., Wang, D., \& Suntu, S. L. (2020). Impact of information technology innovation on firm performance in Kenya. Information Technology for Development, 26(2), 316-345. https://doi.org/10.1080/02681102.2019.1573717

Chen, W., Wei, X., \& Liu, R. (2019). Influence of Interfirm Social Networks on Technological Innovation and its Time Lag Effect: A Meta-Analysis. IEEE Access, 7, 167019-167031. https://doi.org/10.1109/ACCESS.2019.2953977

Chen, Y., \& Ibhagui, O. W. (2019). R\&D-firm performance nexus: New evidence from NASDAQ listed firms. North American Journal of Economics and Finance, 50(January), 101009. https://doi.org/10.1016/j.najef.2019.101009

Chiu, P. C., Teoh, S. H., \& Tian, F. (2013). Board interlocks and earnings management contagion. Accounting Review, 88(3), 915944. https://doi.org/10.2308/accr-50369

Cruz-Cázares, C., Bayona-Sáez, C., \& García-Marco, T. (2013). You can’t manage right what you can’t measure well: Technological innovation efficiency. Research Policy, 42(6-7), 1239-1250. https://doi.org/10.1016/j.respol.2013.03.012

Dimitras, A. I., Kyriakou, M. I., \& Iatridis, G. (2015). Financial crisis, GDP variation and earnings management in Europe. Research in International Business and Finance, 34, 338-354. https://doi.org/10.1016/j.ribaf.2015.02.017

Feeny, S., \& Rogers, M. (2003). Innovation and Performance: Benchmarking Australian Firms. The Australian Economic Review, 36(3), 253-264. https://doi.org/10.1111/1467-8462.00285

Fich, E. M., \& Shivdasani, A. (2012). Are busy boards effective monitors? Corporate Governance: Recent Developments and New Trends, 9783642315(2), 221-258. https://doi.org/10.1007/978-3-642-31579-4_10

Ghapar, F., Brooks, R., \& Smyth, R. (2014). The impact of patenting activity on the financial performance of Malaysian firms. Journal of the Asia Pacific Economy, 19(3), 445-463. https://doi.org/10.1080/13547860.2014.908536

Global Innovation Index. (2019). Rankings 2019. Retrieved from https://www.globalinnovationindex.org/gii-2019-report

Gomes-Casseres, B., Hagedoorn, J., \& Jaffe, A. B. (2006). Do alliances promote knowledge flows? Journal of Financial Economics, 80(1), 5-33. https://doi.org/10.1016/j.jfineco.2004.08.011

Hagspiel, V., Huisman, K. J. M., Kort, P. M., Lavrutich, M. N., Nunes, C., \& Pimentel, R. (2020). Technology adoption in a declining market. European Journal of Operational Research, 285(1), 380-392. https://doi.org/10.1016/j.ejor.2020.01.056

Hamid, A. A. (2011). Network governance in government-linked companies (GLCs) and non-government-linked companies (NGLCs) in Malaysia. Journal of Financial Reporting and Accounting, 9(1), 54-73. https://doi.org/10.1108/19852511111139804

Han, C., Dong, Y., \& Dresner, M. (2012). Emerging Market Penetration, Inventory Supply, and Financial Performance. Production and Operations Management, 1-13. https://doi.org/10.1111/j.1937-5956.2011.01311.x

Han, J., Bose, I., Hu, N., Qi, B., \& Tian, G. (2015). Does director interlock impact corporate R\&D investment? Decision Support Systems, 71, 28-36. https://doi.org/10.1016/j.dss.2015.01.001

Helmers, C., Patnam, M., \& Rau, P. R. (2017). Do board interlocks increase innovation? Evidence from a corporate governance reform in India. Journal of Banking and Finance, 80, 51-70. https://doi.org/10.1016/j.jbankfin.2017.04.001

Hernández-Lara, A. B., \& Gonzales-Bustos, J. P. (2019). The impact of interlocking directorates on innovation: the effects of business and social ties. Management Decision, 57(10), 2799-2815. https://doi.org/10.1108/MD-11-2017-1186

Hervas-Oliver, J. L., Albors Garrigos, J., \& Gil-Pechuan, I. (2011). Making sense of innovation by R\&D and non-R\&D innovators in low technology contexts: A forgotten lesson for policymakers. Technovation, 31(9), $427-446$. https://doi.org/10.1016/j.technovation.2011.06.006

Ho, K. L. P., Nguyen, C. N., Adhikari, R., Miles, M. P., \& Bonney, L. (2018). Exploring market orientation, innovation, and financial performance in agricultural value chains in emerging economies. Journal of Innovation and Knowledge, 3(3), $154-163$. https://doi.org/10.1016/j.jik.2017.03.008 
Homroy, S., \& Slechten, A. (2019). Do Board Expertise and Networked Boards Affect Environmental Performance? Journal of Business Ethics, 158(1), 269-292. https://doi.org/10.1007/s10551-017-3769-y

Jakpar, S., Tinggi, M., \& Hui, T. K. (2019). Analysis of Corporate Governance and Firm Performance: Evidence from Malaysian Listed Companies. International Journal of Business and Social Science, 10(1). https://doi.org/10.30845/ijbss.v10n1p14

Jamaludin, M. F., \& Hashim, F. (2017). Corporate governance, institutional characteristics, and director networks in Malaysia. Asian Academy of Management Journal of Accounting and Finance, 13(2), 135-154. https://doi.org/10.21315/aamjaf2017.13.2.7

Jiang, Y., Yang, Y., Zhao, Y., \& Li, Y. (2020). Partners' centrality diversity and firm innovation performance: Evidence from China. Industrial Marketing Management, 88(March), 22-34. https://doi.org/10.1016/j.indmarman.2020.03.020

Julian, C. C., \& Ahmed, Z. U. (2019). Doing business in Malaysia. Thunderbird International Business Review, 51(1), 53-69. https://doi.org/10.1002/tie.20244

Kim, T. (2019). Financing Technological Innovation: Evidence from Patent-Intensive Firms. Global Economic Review, 48(3), 350362. https://doi.org/10.1080/1226508X.2019.1636702

Koellinger, P. (2008). The relationship between technology, innovation, and firm performance-Empirical evidence from e-business in Europe. Research Policy, 37(8), 1317-1328. https://doi.org/10.1016/j.respol.2008.04.024

Larcker, D. F., So, E. C., \& Wang, C. C. Y. (2013). Boardroom centrality and firm performance. Journal of Accounting and Economics, 55(2-3), 225-250. https://doi.org/10.1016/j.jacceco.2013.01.006

Lee, J., Kwon, H.-B., \& Pati, N. Exploring the relative impact of R\&amp;D and operational efficiency on performance: A sequential regression-neural network approach. Expert Systems with Applications, 137, $420-431$. https://doi.org/10.1016/j.eswa.2019.07.026

Lee, R., Lee, J. H., \& Garrett, T. C. (2019). Synergy effects of innovation on firm performance. Journal of Business Research, 99(August), 507-515. https://doi.org/10.1016/j.jbusres.2017.08.032

Li, M. (2019). Diversity of Board Interlocks and the Impact on Technological Exploration: A Longitudinal Study. In Journal of Product Innovation Management (Vol. 36). https://doi.org/10.1111/jpim.12488

Liao, S., Liu, Z., \& Zhang, S. (2018). Technology innovation ambidexterity, business model ambidexterity, and firm performance in Chinese high-tech firms. Asian Journal of Technology Innovation, 26(3), 325-345. https://doi.org/10.1080/19761597.2018.1549954

Lin, B.-W., Lee, Y., \& Hung, S.-C. (2006). R\&D intensity and commercialization orientation effects on financial performance. Journal of Business Research, 59(6), 679-685. https://doi.org/10.1016/j.jbusres.2006.01.002

Lin, W. L., Yip, N., Ho, J. A., \& Sambasivan, M. (2020). The adoption of technological innovations in a B2B context and its impact on firm performance: An ethical leadership perspective. Industrial Marketing Management, (December 2019). https://doi.org/10.1016/j.indmarman.2019.12.009

Malaysia Productivity Corporation. (2019). Malaysia in the IMD World Competitiveness Yearbook 2019 (p. 40). p. 40. Retrieved from https://www.mida.gov.my/home/administrator/system_files/modules/photo/uploads/20191108171447_World Competitiveness Yearbook 2019.pdf

Medda, G., Piga, C., \& Siegel, D. S. (2006). Assessing the returns to collaborative research: Firm-level evidence from Italy. Economics of Innovation and New Technology, 15(1), 37-50. https://doi.org/10.1080/1043859042000332213

Miller, C. C., Washburn, N. T., \& Glick, W. H. (2013). PERSPECTIVE-The Myth of Firm Performance. Organization Science, 24(3), 948-964. https://doi.org/10.1287/orsc.1120.0762

Neely, A., Gregory, M., \& Platts, K. (2005). Performance measurement system design: A literature review and research agenda. In International Journal of Operations and Production Management (Vol. 25). https://doi.org/10.1108/01443570510633639

Nwosu, H. E., Awurum, J. I., \& Okoli, I. E. (2015). An Evaluation of the Effect of Technological Innovations on Corporate Performance: A Study of Selected Manufacturing Firms in Nigeria. The International Journal Of Business \& Management, 3(1), 248-262. https://doi.org/10.9790/487X-1810048085

OECD/Eurostat. (2018). Oslo Manual 2018: Guidelines for Collecting, Reporting and Using Data on Innovation, 4th Edition, The Measurement of Scientific, Technological and Innovation Activities. In Handbook of Innovation Indicators and Measurement. https://doi.org/10.1787/9789264304604-en

Oh, H., Labianca, G., \& Chung, M. H. (2006). A multilevel model of group social capital. Academy of Management Review, 31(3), 569-582. https://doi.org/10.5465/AMR.2006.21318918

Peng, M. W., Au, K. Y., \& Wang, D. Y. L. (2001). Interlocking directorates as corporate governance in third world multinationals: Theory and evidence from Thailand. Asia Pacific Journal of Management, 18(2), 161-181. https://doi.org/10.1023/A:1010659722213

Pislaru, M., Herghiligiu, I. V., \& Robu, I. B. (2019). Corporate sustainable performance assessment based on fuzzy logic. Journal of Cleaner Production, 223, 998-1013. https://doi.org/10.1016/j.jclepro.2019.03.130

Rahim, F. B. T., \& Zainuddin, Y. Bin. (2019). The impact of technological innovation capabilities on competitive advantage and firm performance in the automotive industry in Malaysia. AIP Conference Proceedings, 2059. https://doi.org/10.1063/1.5085973

Ramli, N. A., Latan, H., \& Solovida, G. T. (2019). Determinants of capital structure and firm financial performance-A PLS-SEM approach: Evidence from Malaysia and Indonesia. Quarterly Review of Economics and Finance, 71, 148-160. https://doi.org/10.1016/j.qref.2018.07.001

Rasiah, R., \& Chandran, V. G. (2015). Unesco Science Report towards $2030 . \quad$ Retrieved from https://en.unesco.org/sites/default/files/usr15_malaysia.pdf

Rasiah, R., \& Yap, X.-S. (2016). Innovation Performance of the Malaysian Economy. The Global Innovation Index $2015,139$. https://doi.org/978-2-9522210-8-5

Ravšelj, D., \& Aristovnik, A. (2020). The Impact of R\&D Expenditures on Corporate Performance: Evidence from Slovenian and World R\&D Companies. Sustainability, 12(5), 1943. https://doi.org/10.3390/su12051943

Rohaida, A. L., Hasnah, K., Kamarun Nisham, T. M., \& Noriah, C. A. (2013). Multiple Directorships, Board Characteristics and Firm Performance in Malaysia. Management, 3(2), 105-111. https://doi.org/10.5923/j.mm.20130302.07

Roper, S., Du, J., \& Love, J. H. (2008). Modelling the innovation value chain. Research Policy, 37(6-7), 961-977. https://doi.org/10.1016/j.respol.2008.04.005

Roudaki, J., \& Bhuiyan, M. B. U. (2015). Interlocking directorship in New Zealand. Australasian Accounting, Business and Finance Journal, 9(3), 45-58. https://doi.org/10.14453/aabfj.v9i3.4 
Ryu, H. S., \& Lee, J. (2015). How non-technological innovation reinforces the effect of technological innovation on firm performance?: An empirical study of Korean manufacturing industry. Communications in Computer and Information Science, 529, $176-182$. https://doi.org/10.1007/978-3-319-21383-5_30

Selvam, M., Gayathri, J., Vasanth, V., Lingaraja, K., \& Marxiaoli, S. (2016). Determinants of Firm Performance: A Subjective Model. International Journal of Social Science Studies, 4(7), 90-100. https://doi.org/10.11114/ijsss.v4i7.1662

Shaw, T. S., Cordeiro, J. J., \& Saravanan, P. (2016). Director network resources and firm performance: Evidence from Indian corporate governance reforms. Asian Business and Management, 15(3), 165-200. https://doi.org/10.1057/s41291-016-0003-1

Singh, D. A., \& Gaur, A. S. (2009). Business group affiliation, firm governance, and firm performance: Evidence from china and india. Corporate Governance: An International Review, 17(4), 411-425. https://doi.org/10.1111/j.1467-8683.2009.00750.x

Taouab, O., \& Issor, Z. (2019). Firm Performance: Definition and Measurement Models. European Scientific Journal ESJ, 15(1), 93106. https://doi.org/10.19044/esj.2019.v15n1p93

Tekic, Z., \& Koroteev, D. (2019). From disruptively digital to proudly analog: A holistic typology of digital transformation strategies. Business Horizons, 62(6), 683-693. https://doi.org/10.1016/j.bushor.2019.07.002

The World Bank. (2020). GDP growth (annual \%) - Malaysia | Data. Retrieved July 13, 2020, from https://data. worldbank.org/indicator/NY.GDP.MKTP.KD.ZG?end=2019\&locations=MY\&start=2010\&view=chart

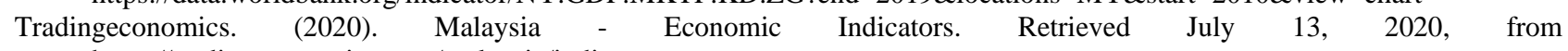
https://tradingeconomics.com/malaysia/indicators

Walsh, S., \& Linton, J. D. (2002). The measurement of technical competencies. Journal of High Technology Management Research, 13(1), 63-86. https://doi.org/10.1016/S1047-8310(01)00049-9

Wang, D. S. (2019). Association between technological innovation and firm performance in small and medium-sized enterprises: The moderating effect of environmental factors. International Journal of Innovation Science, 11(2), $227-240$. https://doi.org/10.1108/IJIS-04-2018-0049

Wang, Z., Jean, R. J. B., \& Zhao, X. (2020). The Direct and Indirect Impact of Relational Ties on Innovation Performance: An Empirical Study in China. IEEE Transactions on Engineering Management, 67(2), $295-308$. https://doi.org/10.1109/TEM.2018.2883484

Wesselman, T. (2017). The Relationship between Corporate Sustainability and Corporate Financial Performance : a conceptual review The Relationship between Corporate Sustainability and Corporate Financial Performance: a conceptual review (Tilburg University). Retrieved from http://arno.uvt.nl/show.cgi?fid=145274

Wincent, J., Anokhin, S., \& Örtqvist, D. (2010). Does network board capital matter? A study of innovative performance in strategic SME networks. Journal of Business Research, 63(3), 265-275. https://doi.org/10.1016/j.jbusres.2009.03.012

Wu, H.-Y., Chen, I.-S., Chen, J.-K., \& Chien, C.-F. (2019). The R\&D efficiency of the Taiwanese semiconductor industry. Measurement, 137, 203-213. https://doi.org/10.1016/j.measurement.2019.01.053

Wu, M., \& Gu, N. (2018). The Impact of Technological Innovation on Corporate Performance: Evidence From the Communication and Cultural Industry in China. International Journal of Financial Research, 9(4), 78. https://doi.org/10.5430/ijfr.v9n4p78

Wu, Y., \& Dong, B. (2020). Independent director network and corporate innovation: evidence from a natural experiment in China. Applied Economics Letters, OO(00), 1-6. https://doi.org/10.1080/13504851.2020.1764475

Xin, K., Chen, X., Zhang, R., \& Sun, Y. (2019). R\&D intensity, free cash flow, and technological innovation: evidence from high-tech manufacturing firms in China. Asian Journal of Technology Innovation, 27(2), $214-238$. https://doi.org/10.1080/19761597.2019.1635894

Yigitcanlar, T., Sabatini-Marques, J., da-Costa, E. M., Kamruzzaman, M., \& Ioppolo, G. (2019). Stimulating technological innovation through incentives: Perceptions of Australian and Brazilian firms. Technological Forecasting and Social Change, 146(August 2016), 403-412. https://doi.org/10.1016/j.techfore.2017.05.039

Yildiz, O., Bozkurt, Ö. Ç., Kalkan, A., \& Ayci, A. (2013). The Relationships between Technological Investment, Firm Size, Firm Age and the Growth Rate of Innovational Performance. Procedia - Social and Behavioral Sciences, 99, 590-599. https://doi.org/10.1016/j.sbspro.2013.10.529

Zuo, L., Fisher, G. J., \& Yang, Z. (2019). Organizational learning and technological innovation: the distinct dimensions of novelty and meaningfulness that impact firm performance. Journal of the Academy of Marketing Science, 47(6), 1166-1183. https://doi.org/10.1007/s11747-019-00633-1 


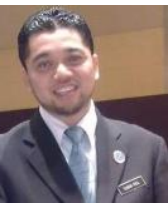

Shah Rol Hussain is Doctoral Candidate of Graduate Business School, Universiti Sains Malaysia. He is presently a member of The Malaysian Institute of Chartered Secretaries and Administrators (MAICSA). His research interests include Firm Performance, Technological Innovation, R\&D, and Directors' Network.

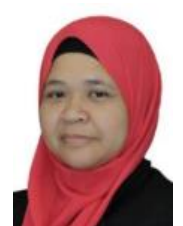

Fathyah Hashim is a senior lecturer at the Graduate School of Business (GSB), Universiti Sains Malaysia (USM). Her area of specialization is in Voluntary Reporting and her research interests include Intellectual Capital, R\&D, and Corporate Social Responsibility Disclosure.

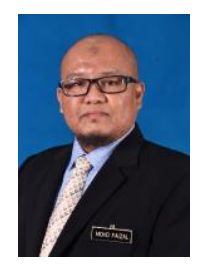

Mohd Faizal Jamaludin is a Senior Lecturer at the Politeknik Tuanku Sultanah Bahiyah, Malaysia. He is appointed as the Head of Research, Innovation and Commercialization Unit. He obtained his Ph.D. in Corporate Governance from Universiti Sains Malaysia. His research interests include corporate governance, political connection, and directors' networks. 